\title{
Global ocean particulate organic carbon flux merged with satellite parameters
}

\author{
Colleen B. Mouw ${ }^{1, a}$, Audrey Barnett ${ }^{1, a}$, Galen A. McKinley ${ }^{2}$, Lucas Gloege ${ }^{2}$, and Darren Pilcher ${ }^{3}$ \\ ${ }^{1}$ Michigan Technological University, 1400 Townsend Drive, Houghton, MI 49931, USA \\ ${ }^{2}$ University of Wisconsin-Madison, 1225 W. Dayton Street, Madison, WI 53706, USA \\ ${ }^{3}$ NOAA, Pacific Marine Environmental Laboratory, 7600 Sand Point Way NE, Seattle, WA 98115, USA \\ anow at: University of Rhode Island, Graduate School of Oceanography, 215 South Ferry Road, Narragansett, \\ RI 02882, USA \\ Correspondence to: Colleen B. Mouw (cmouw @uri.edu)
}

Received: 25 May 2016 - Published in Earth Syst. Sci. Data Discuss.: 17 June 2016

Revised: 29 September 2016 - Accepted: 30 September 2016 - Published: 20 October 2016

\begin{abstract}
Particulate organic carbon (POC) flux estimated from POC concentration observations from sediment traps and ${ }^{234} \mathrm{Th}$ are compiled across the global ocean. The compilation includes six time series locations: CARIACO, K2, OSP, BATS, OFP, and HOT. Efficiency of the biological pump of carbon to the deep ocean depends largely on biologically mediated export of carbon from the surface ocean and its remineralization with depth; thus biologically related parameters able to be estimated from satellite observations were merged at the POC observation sites. Satellite parameters include net primary production, percent microplankton, sea surface temperature, photosynthetically active radiation, diffuse attenuation coefficient at $490 \mathrm{~nm}$, euphotic zone depth, and climatological mixed layer depth. Of the observations across the globe, $85 \%$ are concentrated in the Northern Hemisphere with $44 \%$ of the data record overlapping the satellite record. Time series sites accounted for $36 \%$ of the data, while $71 \%$ of the data are measured at $\geq 500 \mathrm{~m}$ with the most common deployment depths between 1000 and $1500 \mathrm{~m}$. This data set is valuable for investigations of $\mathrm{CO}_{2}$ drawdown, carbon export, remineralization, and sequestration. The compiled data can be freely accessed at doi:10.1594/PANGAEA.855600.
\end{abstract}

\section{Introduction}

Field estimates of particulate organic carbon (POC) flux have been made over many decades in the interest of understanding the biological pump of carbon to the deep ocean. While there have been a variety of new techniques to quantify POC flux, sediment traps have been the most extensive temporally and geographically, and ${ }^{234} \mathrm{Th}$ has improved data resolution in the upper $500 \mathrm{~m}$ of the water column. POC flux depends largely on the biologically mediated export of carbon from the surface ocean and its remineralization with depth, thus capturing biological variables associated with POC flux are essential to understand flux variability. Here we compile POC flux estimated from sediment traps and ${ }^{234} \mathrm{Th}$ from around the globe from public repositories and directly in the literature. We then match the POC flux observations with biological and physical parameters determined from satellite imagery along with mixed layer depth (MLD) climatology. See Table 1 for a list of products and units.

Understanding the impact of surface processes on the export of organic carbon at depth has been an ongoing challenge in the oceanographic community since the Joint Global Ocean Flux Study (JGOFS). Continued efforts with the upcoming Export Processes in the Ocean from RemoTe Sensing (EXPORTS) program along with the Pre-Aerosol, Clouds and ocean Ecosystem (PACE) satellite mission seek to connect remotely sensed estimates of net primary production, particle size distribution, phytoplankton carbon, biomass, and community composition to water column carbon processes. To do this, existing data sources capturing water column processes need to be compiled and synthesized. Our data set provides researchers with access to a comprehensive historical data set of POC flux throughout the global 
Table 1. Summary of data set parameters.

\begin{tabular}{|c|c|c|}
\hline Parameter & Units & Description \\
\hline \multicolumn{3}{|c|}{ Satellite parameters: } \\
\hline chl_gsm & $\mathrm{mg} \mathrm{m}^{-3}$ & Chlorophyll $a$ concentration \\
\hline $\mathrm{kd} 490$ & $\mathrm{~m}^{-1}$ & Diffuse attenuation coefficient for $490 \mathrm{~nm}$ \\
\hline & $\mu \mathrm{mol}$ quanta $\mathrm{m}^{-2} \mathrm{~s}^{-1}$ & Photosynthetically available radiation \\
\hline pp_vgpm & $\mathrm{mg} \mathrm{C} \mathrm{m}^{-2} \mathrm{~d}^{-1}$ & Net primary production \\
\hline sfm & $\%$ & Microplankton fraction \\
\hline sst & ${ }^{\circ} \mathrm{C}$ & Sea surface temperature \\
\hline zeu & $\mathrm{m}$ & Base of the euphotic zone \\
\hline \multicolumn{3}{|l|}{ In situ fluxes: } \\
\hline al_flux & $\mu g \mathrm{~m}^{-2} \mathrm{~d}^{-1}$ & Flux of particulate aluminum \\
\hline ba_flux & $\mu \mathrm{g} \mathrm{m}^{-2} \mathrm{~d}^{-1}$ & Flux of barium \\
\hline caco3_flux & $\mathrm{mg} \mathrm{m}^{-2} \mathrm{~d}^{-1}$ & Flux of particulate calcium carbonate \\
\hline chl_flux & $\mathrm{mg} \mathrm{m}^{-2} \mathrm{~d}^{-1}$ & Flux of chl \\
\hline detrital_flux & $\mathrm{mg} \mathrm{m}^{-2} \mathrm{~d}^{-1}$ & Flux of detrital particles \\
\hline mass_flux & $\mathrm{mg} \mathrm{m}^{-2} \mathrm{~d}^{-1}$ & Total mass flux \\
\hline mn_flux & $\mu g \mathrm{~m}^{-2} \mathrm{~d}^{-1}$ & Flux of manganese \\
\hline pheo_flux & $\mathrm{mg} \mathrm{m}^{-2} \mathrm{~d}^{-1}$ & Flux of phaeopigments \\
\hline pic_flux & $\mathrm{mg} \mathrm{m}^{-2} \mathrm{~d}^{-1}$ & Flux of particulate inorganic carbon \\
\hline poc_flux & $\mathrm{mg} \mathrm{m}^{-2} \mathrm{~d}^{-1}$ & Flux of particulate organic carbon \\
\hline pon_flux & $\mathrm{mg} \mathrm{m}^{-2} \mathrm{~d}^{-1}$ & Flux of particulate organic nitrogen \\
\hline pop_flux & $\mathrm{mg} \mathrm{m}^{-2} \mathrm{~d}^{-1}$ & Flux of particulate organic phosphorus \\
\hline si_flux & $\mathrm{mg} \mathrm{m}^{-2} \mathrm{~d}^{-1}$ & Flux of total particulate silica \\
\hline sio2_flux & $\mathrm{mg} \mathrm{m}^{-2} \mathrm{~d}^{-1}$ & Flux of particulate silica, in the form of $\mathrm{SiO}_{2}$ \\
\hline sio4_flux & $\mathrm{mg} \mathrm{m}^{-2} \mathrm{~d}^{-1}$ & Flux of particulate silica, in the form $\mathrm{SiO}_{4}$ \\
\hline tc flux & $\mathrm{mg} \mathrm{m}^{-2} \mathrm{~d}^{-1}$ & Flux of total particulate carbon \\
\hline ti_flux & $\mu \mathrm{g} \mathrm{m}^{-2} \mathrm{~d}^{-1}$ & Flux of titanium \\
\hline \multicolumn{3}{|c|}{ Mixed layer depth climatology: } \\
\hline mld & $\mathrm{m}$ & Mixed layer depth \\
\hline \multicolumn{3}{|l|}{ Bathymetry: } \\
\hline bathymetry & $\mathrm{m}$ & Total water column depth \\
\hline
\end{tabular}

ocean along with matched environmental parameters derived from remote sensing sources. The community can use this resource to move further towards a mechanistic understanding of the biological pump.

\section{Data and methodology}

\subsection{Satellite products and mixed layer depth}

We provide products derived from SeaWiFS (Sea-viewing Wide Field-of-view Sensor) monthly global area coverage (level 3 mapped data, $9 \mathrm{~km}, 8$-day resolution, version R2014) imagery over the mission record (September 1997-December 2010) acquired from NASA Ocean Biology Distributed Active Archive Center (OB.DAAC) (http: //oceancolor.gsfc.nasa.gov/). These include chlorophyll concentration ([Chl]) (Maritorena et al., 2002), diffuse attenua- tion coefficient at $490 \mathrm{~nm}\left(K_{\mathrm{d}}(490)\right)$ (O'Reilly et al., 2000), and photosynthetically available radiation (PAR) (Frouin et al., 2002). At the time of writing, only $8 \%$ of the publicly available POC observations were measured beyond 2008, when the MODerate resolution Imaging Spectroradiometer (MODIS) replaced the SeaWiFS record, and thus we focus our data compilation here solely on SeaWiFS. Net primary production (NPP) estimates from the Vertically Generalized Production Model (VGPM) (Behrenfeld and Falkowski, 1997) are obtained from http://www.science.oregonstate. edu/ocean.productivity/ ( $9 \mathrm{~km}, 8$-day resolution). SeaWiFS data products and NPP are retrieved as the median of a $5 \times 5$ pixel box $\left(2025 \mathrm{~km}^{2}\right)$ centered on each POC flux location (Bailey and Werdell, 2006). AVHRR Pathfinder Version 5 (4 km, 8-day resolution) sea surface temperature (SST) imagery was acquired from the US National Oceanographic 


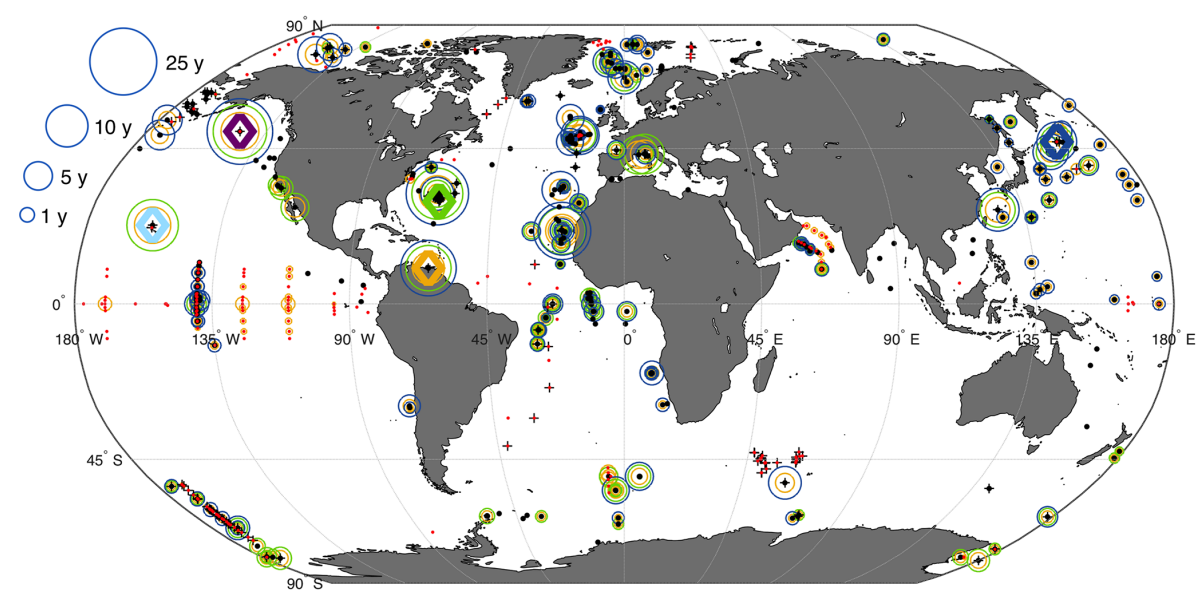

Figure 1. Geographical distribution of POC flux observations at 673 independent sites. The size of the circle indicates the length of the data record at a given site (see legend). The color of the circles indicate the depth of observation, where orange is $\leq 100 \mathrm{~m}$, green is $>100$ and $\leq 1000 \mathrm{~m}$, and dark blue is $>1000 \mathrm{~m}$. The location of sediment trap is indicated in black and the location of ${ }^{234} \mathrm{Th}$ data is in red. Plus symbols (+) indicate which observations are during the satellite era (i.e., September 1997-present). The diamonds highlight the locations of time series sites; BATS/OFP (green, $14 \%$ ), CARIACO (orange, 10\%), K2 (dark blue, $2 \%$ ), OSP (purple, $7 \%$ ), and HOT (light blue, $3 \%$ ) account for $36 \%$ of the data record.

Data Center and GHRSST (http://pathfinder.nodc.noaa.gov) (Casey et al., 2010). To match the spatial resolution of SeaWiFS as much as possible, SST was retrieved as the median of an $11 \times 11$ pixel box $\left(1936 \mathrm{~km}^{2}\right)$ centered on each POC flux location.

The Mouw and Yoder (2010) approach is used for satellite retrieval of phytoplankton size classes from SeaWiFS imagery $(9 \mathrm{~km}$, monthly resolution). The imagery files were obtained from: doi:10.1594/PANGAEA.860474. The method estimates the percentage of microplankton $\left(S_{\mathrm{fm}}\right)$ from satellite imagery of remote sensing reflectance $\left(R_{\mathrm{rS}}(\lambda)\right)$. This is an absorption-based approach where the chlorophyll-specific absorption spectra for phytoplankton size class extremes, pico- $(0.2-2 \mu \mathrm{m})$ and microplankton $(>20 \mu \mathrm{m})$, are weighted by $S_{\mathrm{fm}}$ (Ciotti et al., 2002; Ciotti and Bricaud, 2006). Briefly, $S_{\mathrm{fm}}$ is estimated from a look-up table containing simulated chlorophyll [Chl], absorption due to dissolved and detrital material at $443 \mathrm{~nm}\left(a_{\mathrm{cdm}}(443)\right), R_{\mathrm{rs}}(\lambda)$, and $S_{\mathrm{fm}}$. For a given pixel, satellite-estimated [Chl] and $a_{\mathrm{cdm}}(443)$ (Maritorena et al., 2002) are used to narrow the search space within the look-up table. Of the remaining options, the closest simulated $R_{\mathrm{rs}}(\lambda)$ to the satellite-observed $R_{\mathrm{rs}}(\lambda)$ is selected and the associated $S_{\mathrm{fm}}$ is assigned. $S_{\mathrm{fm}}$ is retrieved on a monthly timescale as the median of a $5 \times 5$ pixel box $\left(2025 \mathrm{~km}^{2}\right)$ centered on each POC flux location.

Export depth is often chosen as either the base of the euphotic zone or MLD (Lutz et al., 2007; Lam et al., 2011); thus both are compiled here. The depth of the euphotic zone was determined from $K_{\mathrm{d}}(490)$ (O'Reilly et al., 2000 ) as $4.6 / K_{\mathrm{d}}(490)$ (Morel and Berthon, 1989) from 8day SeaWiFS data products. MLD estimates are obtained from the IFREMER/LOS Mixed Layer Depth Climatol- ogy group (http://www.ifremer.fr/cerweb/deboyer/mld) from density profiles using a variable density threshold equivalent to $0.2{ }^{\circ} \mathrm{C}$, which accounts for both changes in temperature and salinity (level 3 , monthly climatology, $1^{\circ}$ resolution; de Boyer Montégut et al., 2004, 2007; Mignot et al., 2007). We retrieve monthly MLD climatology for each pixel containing a POC flux location $\left(1^{\circ}\right.$ resolution).

\subsection{POC flux data}

POC sediment trap data are acquired from public repositories and published literature (Table 2; Fig. 1). Estimates from ${ }^{234} \mathrm{Th}$ measurements are also acquired to improve the resolution of observations in the upper $500 \mathrm{~m}$ of the water column (Dunne et al., 2005; Henson et al., 2012; Guidi et al., 2015). These represent $4 \%$ of the total data set. Collected field estimates of POC flux derived from ${ }^{234} \mathrm{Th}$ maintain the original authors' analysis, where POC flux is retrieved based on ${ }^{234} \mathrm{Th}$ activity in the water column accounting for the ratio of POC to ${ }^{234} \mathrm{Th}$ concentration (Buesseler and Boyd, 2009). Both sediment traps and ${ }^{234} \mathrm{Th}$ methodologies have documented challenges associated with accurately retrieving POC flux and characterizing uncertainty. Sediment traps have possible bias associated with the interaction of hydrodynamics with trap design, the capture of zooplankton ("swimmers"), and incomplete preservation of material. ${ }^{234} \mathrm{Th}$-based measurements have associated biases accounting for local advection, quantifying particulate adsorption and with variability in the ratio of POC: ${ }^{234} \mathrm{Th}$. See the discussions of Buesseler (1991), Buesseler et al. (2000), Lee et al. (1992), Murray et al. (1996), Quay (1997), and van der Loeff et al. (2006), for in-depth analyses of these issues. 
Table 2. Summary of data sources for POC flux from sediment traps and ${ }^{234} \mathrm{Th}$, the latter indicated in the description when applicable. Date ranges are from first deployment to last retrieval for a given data set, but do not necessarily indicate a continuous time series. Sources are listed in order of first deployment.

\begin{tabular}{|c|c|c|c|}
\hline $\begin{array}{l}\text { Latitude/longitude } \\
\text { range }\end{array}$ & $\begin{array}{l}\text { Date range } \\
\text { yyyy-mm-dd }\end{array}$ & $\begin{array}{l}\text { Description/ } \\
\text { project }\end{array}$ & Reference \\
\hline $\begin{array}{l}78.9^{\circ} \mathrm{N}-76.5^{\circ} \mathrm{S} \\
\text { All }\end{array}$ & $1976-07-04$ to $2005-05-09$ & Global collection & Lutz et al. (2007) and references therein \\
\hline $\begin{array}{l}81.1^{\circ} \mathrm{N}-71.1^{\circ} \mathrm{S} \\
138.9^{\circ} \mathrm{E}-74.2^{\circ} \mathrm{W}\end{array}$ & $1982-06-07$ to $2007-06-04$ & Atlantic Ocean Data Compilation & Torres Valdés et al. (2014) \\
\hline $\begin{array}{l}50^{\circ} \mathrm{N} \\
145^{\circ} \mathrm{W}\end{array}$ & $1987-09-23$ to $2006-06-04$ & Ocean Station Papa & Timothy et al. (2013) \\
\hline $\begin{array}{l}60.3^{\circ} \mathrm{N}-67.8^{\circ} \mathrm{S} \\
\text { All }\end{array}$ & $1987-06-06$ to $2009-08-08$ & Global collection of ${ }^{234} \mathrm{Th}$ & $\begin{array}{l}\text { Henson et al. (2011) and references } \\
\text { therein }\end{array}$ \\
\hline $\begin{array}{l}22.8^{\circ} \mathrm{N} \\
158^{\circ} \mathrm{W}\end{array}$ & $1988-12-01$ to $2010-10-05$ & HOT, station ALOHA & Church and Karl (2013) \\
\hline $\begin{array}{l}32.7-30.6^{\circ} \mathrm{N} \\
63.1-65.3^{\circ} \mathrm{W}\end{array}$ & $1988-12-16$ to $2011-12-10$ & BATS & $\begin{array}{l}\text { http://bats.bios.edu, last access: } \\
27 \text { September } 2013\end{array}$ \\
\hline $\begin{array}{l}48-34^{\circ} \mathrm{N} \\
21^{\circ} \mathrm{W}\end{array}$ & $1989-04-03$ to $1990-04-02$ & $\begin{array}{l}\text { JGOFS North Atlantic Bloom Ex- } \\
\text { periment }\end{array}$ & Honjo and Manganini (1995) \\
\hline $\begin{array}{l}31.8^{\circ} \mathrm{N} \\
64.2^{\circ} \mathrm{W}\end{array}$ & $1989-06-09$ to $2010-11-09$ & Ocean Flux Program & $\begin{array}{l}\text { M. Conte (personal communication, } \\
\text { 2015) }\end{array}$ \\
\hline $\begin{array}{l}12^{\circ} \mathrm{N}-12^{\circ} \mathrm{S} \\
140^{\circ} \mathrm{W}\end{array}$ & $1992-01-18$ to $1993-02-04$ & JGOFS Equatorial Pacific & $\begin{array}{l}\text { Collier and Dymond (1994a, b); } \\
\text { Honjo and Dymond (1994); } \\
\text { Newton and Murray (1995a, b) }\end{array}$ \\
\hline $\begin{array}{l}12^{\circ} \mathrm{N}-12^{\circ} \mathrm{S} \\
135-140^{\circ} \mathrm{W}\end{array}$ & $1992-02-04$ to $1992-09-13$ & JGOFS Equatorial Pacific, ${ }^{234} \mathrm{Th}$ & Murray et al. (1996) \\
\hline $\begin{array}{l}77-80^{\circ} \mathrm{N} \\
8-16^{\circ} \mathrm{W}\end{array}$ & $1992-07-19$ to $1993-08-11$ & $\begin{array}{l}\text { Northeast Water Polyna, Green- } \\
\text { land, }{ }^{234} \mathrm{Th}\end{array}$ & Cochran et al. (1995) \\
\hline $\begin{array}{l}43.2^{\circ} \mathrm{N} \\
5.2^{\circ} \mathrm{W}\end{array}$ & $1993-10-16$ to $2006-01-15$ & Mediterranean Sea & Rigual-Hernández et al. (2013) \\
\hline $\begin{array}{l}55-88^{\circ} \mathrm{N} \\
34^{\circ} \mathrm{E}-176^{\circ} \mathrm{W}\end{array}$ & $1994-08-01$ to $1999-07-01$ & Arctic Ocean, ${ }^{234} \mathrm{Th}$ & Wassmann et al. (2003) \\
\hline $\begin{array}{l}2^{\circ} \mathrm{N}-2^{\circ} \mathrm{S} \\
175^{\circ} \mathrm{E}-177^{\circ} \mathrm{W}\end{array}$ & $1994-10-06$ to $1996-05-01$ & $\begin{array}{l}\text { FLUPAC and Zonal Flux Study, } \\
\text { Western Equatorial Pacific, }{ }^{234} \mathrm{Th}\end{array}$ & Dunne et al. (2000) \\
\hline $\begin{array}{l}17.7-10.0^{\circ} \mathrm{N} \\
57.8-65.0^{\circ} \mathrm{E}\end{array}$ & $1994-11-11$ to $1995-12-24$ & JGOFS Arabian Sea & Honjo (1999) \\
\hline $\begin{array}{l}10.3^{\circ} \mathrm{N} \\
64.4^{\circ} \mathrm{W}\end{array}$ & $1995-11-08$ to $2012-12-10$ & CARIACO & Thurnell (2013) \\
\hline $\begin{array}{l}61.5-22.0^{\circ} \mathrm{N} \\
160^{\circ} \mathrm{E}-170^{\circ} \mathrm{W}\end{array}$ & $1996-05-15$ to $2005-08-15$ & Review of ${ }^{234} \mathrm{Th}$ measurements & $\begin{array}{l}\text { Buesseler and Boyd (2009) and refer- } \\
\text { ences therein }\end{array}$ \\
\hline $\begin{array}{l}73.6-76.5^{\circ} \mathrm{S} \\
176.9^{\circ} \mathrm{E}-178.0^{\circ} \mathrm{W}\end{array}$ & $1996-06-12$ to $1999-07-25$ & Ross Sea & Collier et al. (2000) \\
\hline $\begin{array}{l}73.6-76.5^{\circ} \mathrm{S} \\
177^{\circ} \mathrm{E}-178.0^{\circ} \mathrm{W}\end{array}$ & $1996-10-18$ to $1997-04-30$ & Ross Sea, ${ }^{234} \mathrm{Th}$ & Cochran et al. (2000) \\
\hline $\begin{array}{l}53.0-76.5^{\circ} \mathrm{S} \\
\text { Circumpolar }\end{array}$ & $1996-11-28$ to $1998-01-27$ & JGOFS Southern Ocean & Honjo and Dymond (2002) \\
\hline $\begin{array}{l}53.0-70^{\circ} \mathrm{S} \\
\text { Circumpolar }\end{array}$ & $1997-10-23$ to $1998-03-13$ & JGOFS Southern Ocean, ${ }^{234} \mathrm{Th}$ & Buesseler et al. (2003) \\
\hline $\begin{array}{l}39-25^{\circ} \mathrm{N} \\
147-137^{\circ} \mathrm{E}\end{array}$ & $1997-11-19$ to $1999-08-12$ & Kuroshio Extension, Pacific & Mohiuddin et al. (2002) \\
\hline $\begin{array}{l}36.7-36.0^{\circ} \mathrm{N} \\
147-154.9^{\circ} \mathrm{E}\end{array}$ & $1998-08-29$ to $2000-08-29$ & Kuroshio Extension, Pacific & Mohiuddin et al. (2004) \\
\hline $\begin{array}{l}44^{\circ} \mathrm{N} \\
155.1^{\circ} \mathrm{E}\end{array}$ & $1998-11-02$ to $1999-05-26$ & North Pacific & Honda et al. (2002) \\
\hline $\begin{array}{l}62.6^{\circ} \mathrm{S} \\
178.1^{\circ} \mathrm{W}\end{array}$ & $1999-02-12$ to $2001-09-17$ & Antarctic Polar Front & Tesi et al. (2012) \\
\hline
\end{tabular}


Table 2. Continued.

\begin{tabular}{|c|c|c|c|}
\hline $\begin{array}{l}\text { Latitude/longitude } \\
\text { range }\end{array}$ & $\begin{array}{l}\text { Date range } \\
\text { yyyy-mm-dd }\end{array}$ & $\begin{array}{l}\text { Description/ } \\
\text { project }\end{array}$ & Reference \\
\hline $\begin{array}{l}77.0-77.8^{\circ} \mathrm{S} \\
172.5-180^{\circ} \mathrm{W}\end{array}$ & $2001-12-22$ to $2006-02-03$ & Ross Sea, Antarctica & Smith Jr. et al. (2011) \\
\hline $\begin{array}{l}51-39^{\circ} \mathrm{N} \\
155-165^{\circ} \mathrm{E}\end{array}$ & $2002-10-16$ to $2005-03-06$ & NW Pacific, ${ }^{234} \mathrm{Th}$ & Kawakami and Honda (2007) \\
\hline $\begin{array}{l}43.3^{\circ} \mathrm{N} \\
7.7^{\circ} \mathrm{E}\end{array}$ & $2003-03-06$ to $2005-04-28$ & MedFlux, Mediterranean Sea & Lee (2011) \\
\hline $\begin{array}{l}33.6^{\circ} \mathrm{N} \\
118.4^{\circ} \mathrm{W}\end{array}$ & 2004-01-07 to $2008-06-19$ & Southern California Bight & Collins et al. (2011) \\
\hline $\begin{array}{l}34.9-29.6^{\circ} \mathrm{N} \\
58.2-67.2^{\circ} \mathrm{W}\end{array}$ & $2004-02-22$ to $2005-03-13$ & $\begin{array}{l}\text { New Production During Winter } \\
\text { Convective Mixing Events }\end{array}$ & Lomas et al. (2009) \\
\hline $\begin{array}{l}47.0-22.8^{\circ} \mathrm{N} \\
161^{\circ} \mathrm{E}-158^{\circ} \mathrm{W}\end{array}$ & $2004-06-22$ to $2005-08-10$ & VERTIGO, Pacific & Lamborg et al. (2008) \\
\hline $\begin{array}{l}47-30^{\circ} \mathrm{N} \\
145-160^{\circ} \mathrm{E}\end{array}$ & $2005-03-21$ to $2011-07-24$ & $\begin{array}{l}\text { OceanSITES, K2 and S1, NW Pa- } \\
\text { cific }\end{array}$ & Honda (2012) \\
\hline $\begin{array}{l}44.6^{\circ} \mathrm{N} \\
2.8^{\circ} \mathrm{W}\end{array}$ & $2006-06-22$ to $2006-06-26$ & Bay of Biscay & Kuhnt et al. (2013) \\
\hline $\begin{array}{l}10.3^{\circ} \mathrm{N} \\
64.4^{\circ} \mathrm{W}\end{array}$ & $2007-02-28$ to $2008-12-31$ & CARIACO & Montes et al. (2012) \\
\hline $\begin{array}{l}62.3-55.3^{\circ} \mathrm{N} \\
167.9-176.8^{\circ} \mathrm{W}\end{array}$ & $2008-03-30$ to $2008-07-03$ & Bering Sea & Moran et al. (2012) \\
\hline $\begin{array}{l}61.1^{\circ} \mathrm{N} \\
26.5^{\circ} \mathrm{W}\end{array}$ & $2008-05-05$ to $2008-05-19$ & North Atlantic Spring Bloom & Martin et al. (2011) \\
\hline
\end{tabular}

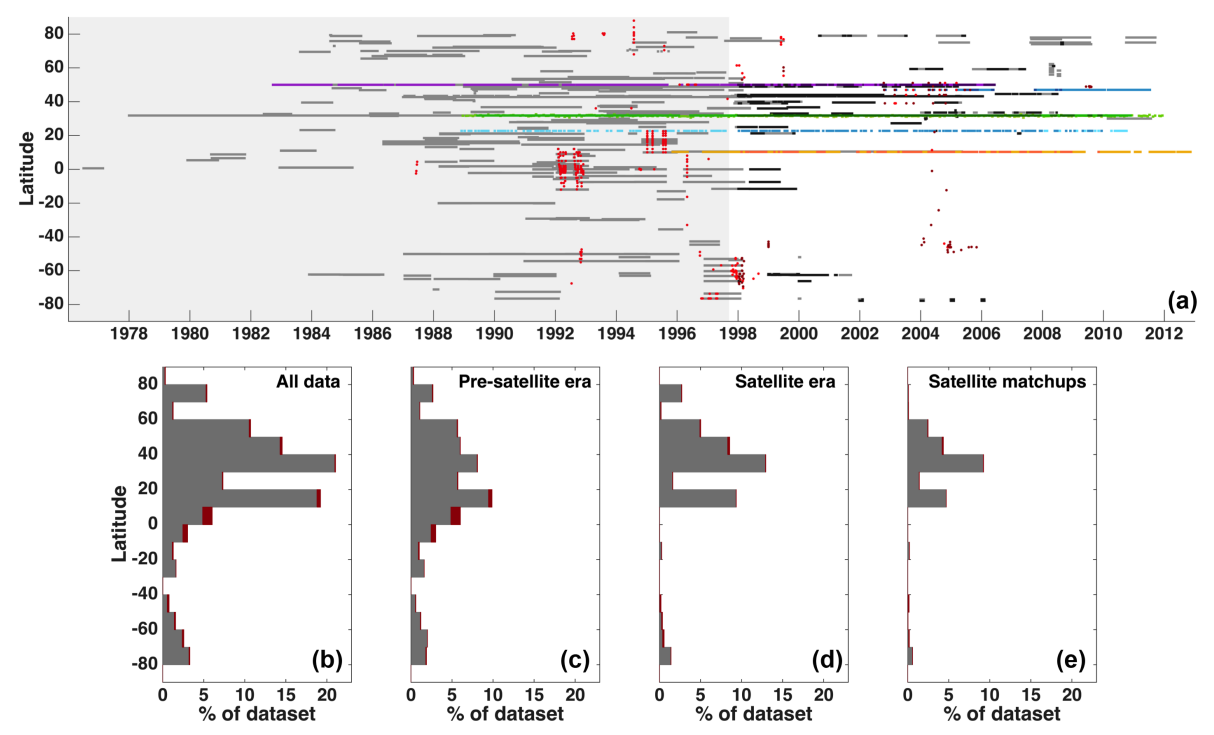

Figure 2. Latitudinal distribution of POC flux observations. (a) Temporal distribution showing observations prior to (shaded area) and during (right panel) the satellite era. The length of each grey bar represents a sediment trap deployment (darker bars indicate observations coincident with satellite NPP and $S_{\mathrm{fm}}$ ); note some bars may overlap. Time series locations are denoted by color as in Fig. $1 .{ }^{234} \mathrm{Th}$ data are differentiated in all subplots (red). (b) The percentage of total observations binned by every $10^{\circ}$ of latitude. (c) Observations prior to the continuous satellite era (before September 1997). (d) Observations collected during the continuous satellite era (beginning September 1997). (e) Observations with coincident satellite imagery within the same month of collection.

A significant number of studies occurred prior to the launch of SeaWiFS in September 1997 (see Honjo et al., 2008, and references therein). While we compiled observa- tions across all available time frames, greater focus is placed on collecting data concurrent with the satellite record to allow corresponding imagery-based environmental parameters 


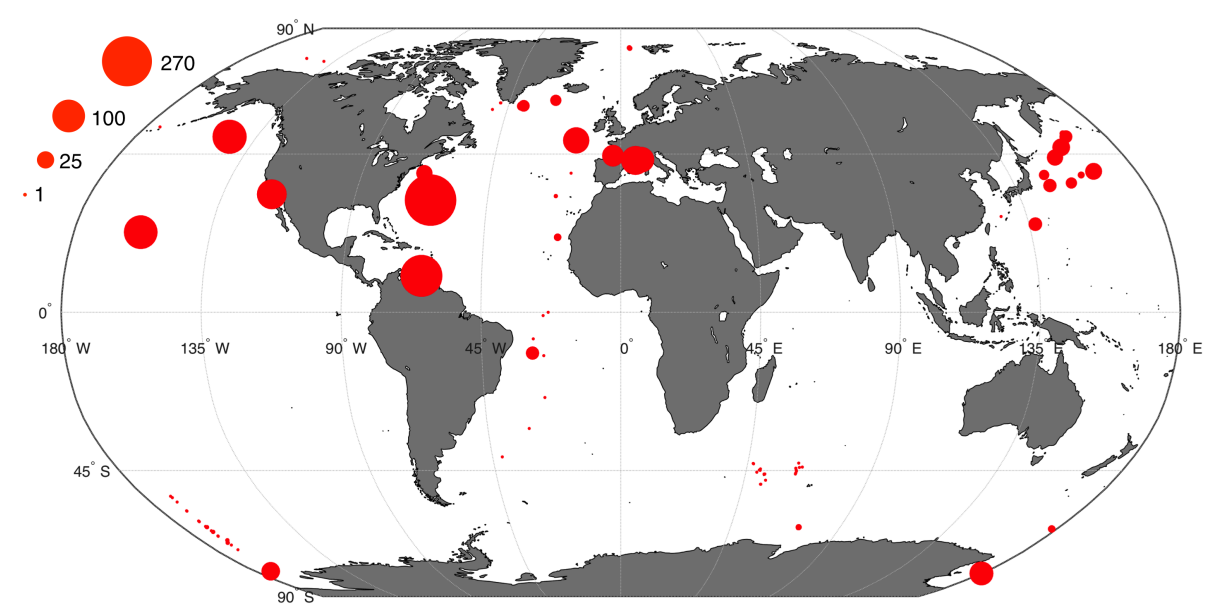

Figure 3. Spatial distribution of coincident satellite and POC flux observations. The size of the circle represents the number of coincident observations (see legend).

to be matched. Overall, the data set comprises a total of 15792 individual measurements at 673 unique locations with $6842(43 \%)$ collected during the satellite record. In the interest of matching the timescale of POC flux to satellite-derived products to the greatest degree possible, we focused on collecting short-term sediment trap deployments with individual cup intervals of 30 days or less. The majority of the data set (14555 measurements or $92 \%$ ) fell into this category with a median cup interval of 14 days and a standard deviation of 6 days. Data are skewed towards shorter deployments with $59 \%$ of qualified measurements deployed 14 days or less and $93 \%$ deployed 20 days or less.

\subsection{Time series sites}

Six long-term oceanographic time series locations are included in the compilation, providing detailed temporal resolution of POC flux export and remineralization. These were the Carbon Retention In A Colored Ocean (CARI$\mathrm{ACO})$ project site in the Cariaco Basin $\left(10.5^{\circ} \mathrm{N}, 64.7^{\circ} \mathrm{W}\right)$, $\mathrm{K} 2$ in the northwest Pacific $\left(47^{\circ} \mathrm{N}, 160^{\circ} \mathrm{E}\right)$, Ocean Station Papa $\left(50^{\circ} \mathrm{N}, 145^{\circ} \mathrm{W}\right)$, the Bermuda Atlantic Time Series (BATS) study site in the Sargasso Sea $\left(31.7^{\circ} \mathrm{N}, 64.2^{\circ} \mathrm{W}\right)$, the Ocean Flux Program (OFP; $31.8^{\circ} \mathrm{N}, 64.2^{\circ} \mathrm{W}$ ), and the Hawaii Ocean Timeseries (HOT; $22.8^{\circ} \mathrm{N}, 158.0^{\circ} \mathrm{W}$ ). Data from BATS and OFP could be combined to create a complete water column profile with BATS sediment traps deployed $\leq 300 \mathrm{~m}$ and OFP traps deployed $\geq 500 \mathrm{~m}$. Also, with the exception of the first deployment year, HOT only reports POC flux at a single depth.

\subsection{Fluxes of other constituents, uncertainty estimates, and metadata}

Where readily available, we collect concurrent flux estimates of other organic and inorganic components in addition to

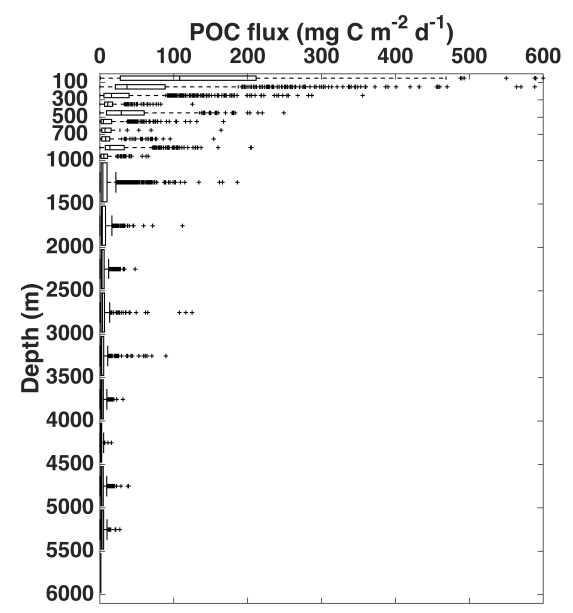

Figure 4. Global POC flux variability with depth. POC flux observations are binned every $100 \mathrm{~m}$ in the upper $1000 \mathrm{~m}$ and every $500 \mathrm{~m}$ throughout the rest of the water column. Box edges enclose the 25 th and 75 th percentiles of data within each bin with the median shown as a vertical line. Error bars extend to the 5th and 95th percentiles and remaining outliers are indicated with + . There are eight data points not represented on the plot, as they were significantly higher than the majority of the data set. These values were observed $<225 \mathrm{~m}$ and are $620,660,677,694,830,852,950$, and $1238 \mathrm{mg} \mathrm{C} \mathrm{m}^{-2} \mathrm{~d}^{-1}$.

POC flux including particulate inorganic carbon, particulate nitrogen and phosphorus, calcium carbonate, biogenic silica, trace metals, and phytoplankton pigments (Table 1). These data are included to explore relationships between POC export and remineralization and ballasting materials. Where reported by the original authors, we include uncertainty estimates for measured fluxes in the compilation. We also collect and include metadata as reported by the original authors. At a minimum, we require each observation be associated 


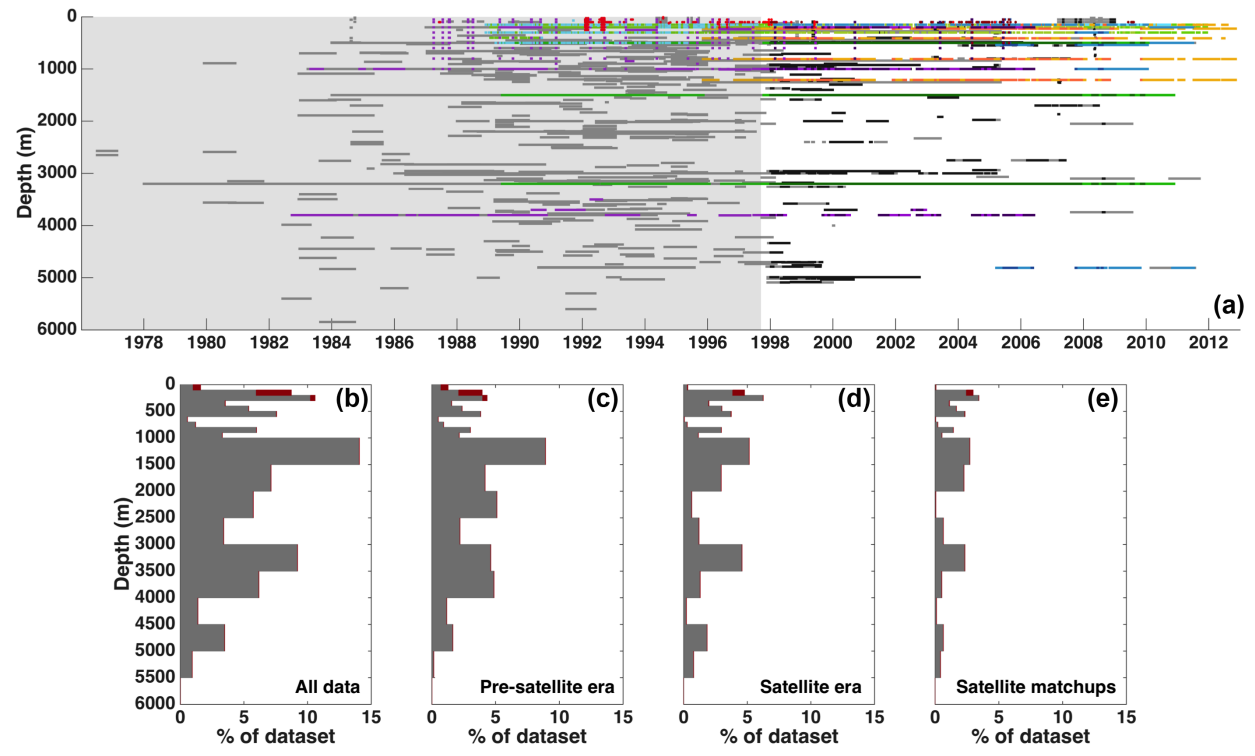

Figure 5. Depth distribution of POC flux observations. The percentage of total observations was binned every $100 \mathrm{~m}$ in the upper $1000 \mathrm{~m}$ and every $500 \mathrm{~m}$ throughout the rest of the water column. Coloration is the same as in Fig. 2. (a) Temporal distribution indicates observations prior to (shaded area) and during (right panel) the satellite era. (b) The percentage of depth dinned total observations. (c) Observations prior to the continuous satellite era (before September 1997). (d) Observations collected during the continuous satellite era (beginning September 1997). (e) Observations with coincident satellite imagery within the same month of observation.

with latitude and longitude, deployment date, and depth to be included in the data set. Other information, such as sediment trap type and trap funnel area, is included where available. The majority of measurements $(58 \%)$ were not associated with a reported total water depth. Bathymetry was retrieved for POC flux locations from the ETOPO1 1 arcmin Global Relief Model (Amante and Eakins, 2009) from the single pixel containing the measurement location. Locations close to shore were sometimes classified as being on land by ETOPO1; bathymetry is excluded in these cases.

\section{Results}

The deployment, retrieval, and analysis of sediment trap and ${ }^{234} \mathrm{Th}$ samples represents a significant expenditure of both effort and resources and projects are often funded on a shortterm local/regional basis (Honjo et al., 2008). This is reflected in the patchy distribution of observations across the globe in multiple dimensions: space, time, and vertical resolution (Fig. 1). Collection efforts are more prevalent in the Northern Hemisphere, with $63 \%$ of unique station locations comprising $85 \%$ of total observations falling north of the Equator (Fig. 2a and b). Long-term oceanographic time series locations at BATS/OFP, CARIACO, K2, OSP, and HOT (all in the Northern Hemisphere) collectively account for $36 \%$ of the total data set. If time series locations are removed, $77 \%$ of remaining observations still concentrate north of the Equator. The most sampled regions in the Northern Hemisphere are at midlatitudes, with a quarter of the data set (discounting time series locations) falling between 30 and $40^{\circ} \mathrm{N}$ (Fig. 2b). In the Southern Hemisphere, data are concentrated at higher latitudes, with a little over half of collected measurements derived from the Southern Ocean at $\geq 60^{\circ} \mathrm{S}$. In both hemispheres, the second-most sampled latitudes are near the Equator $\left(10^{\circ} \mathrm{N}-10^{\circ} \mathrm{S}\right)$.

The data set spans 4 decades from 1976 to 2012 with the majority of efforts (62\%) deployed between 1990 and 2000 (Fig. 2, Table 2). In addition, $43 \%$ of the measurements were collected after September 1997, when the SeaWiFS mission was launched. Prior to SeaWiFS, $79 \%$ of observations are in the Northern Hemisphere (Fig. 2c). After September 1997, the latitudinal distribution becomes even more skewed with $93 \%$ of the observations in the Northern Hemisphere concurrent with the satellite record (Fig. 2d).

While $43 \%$ of the data were observed during the continuous satellite era, not all observations had coincidental imagery. Here we define coincident as retrieved satellite observations within the same month as sediment trap deployment or ${ }^{234} \mathrm{Th}$ measurement for a given POC flux location. We consider only the $S_{\mathrm{fm}}$ and NPP imagery for this purpose as they are representative of phytoplankton surface processes and the NPP product already requires SST and [Chl] imagery as inputs. This reduces the total satellite era observations from 6842 to 3722 , a drop in total contribution from 43 to $24 \%$. These are spread over 121 unique locations (Fig. 3). Of the coincident observations, $95 \%$ are in the Northern Hemisphere primarily between 10 and $50^{\circ} \mathrm{N}$, with the majority found between 30 and $40^{\circ} \mathrm{N}$ (Fig. 2e). Data sets in some re- 
gions of the ocean (e.g., the equatorial Pacific and the Arabian Sea in Fig. 1) have no satellite overlap (Fig. 3).

The depth resolution of the observations is important for investigators interested in fitting export flux relationships (Martin et al., 1987; Lima et al., 2014). The greatest variability in POC flux is found in the first $500 \mathrm{~m}$ of the water column (Lam et al., 2011, Fig. 4). Considering all POC observations together, median POC flux rapidly diminishes from $160 \mathrm{mg} \mathrm{C} \mathrm{m}^{-2} \mathrm{~d}^{-1}$ in the upper $100 \mathrm{~m}$ to $30 \mathrm{mg} \mathrm{C} \mathrm{m}^{-2} \mathrm{~d}^{-1}$ at $500 \mathrm{~m}$ and $6 \mathrm{mg} \mathrm{C} \mathrm{m}^{-2} \mathrm{~d}^{-1}$ at $1000 \mathrm{~m}$. Below $1000 \mathrm{~m}$, the average POC flux is $3 \mathrm{mg} \mathrm{C} \mathrm{m}^{-2} \mathrm{~d}^{-1}$ (Fig. 4).

Overall, $70 \%$ of the compiled data set is measured at $\geq 500 \mathrm{~m}$ (Fig. 5). Thus, the upper water column close to the depth of export is relatively underrepresented. To increase depth resolution, we consider ${ }^{234} \mathrm{Th}$ and sediment traps together (Dunne et al., 2005; Guidi et al., 2015). Guidi et al. (2015) also merged data from the underwater vision profiler (UVP), which is not included in this compilation as it has not yet been released into a public archive. Shallow observations are critical for capturing the impact of phytoplankton on POC export flux as these data are most connected to surface processes. By adding ${ }^{234} \mathrm{Th}$ measurements to the data set, 249 locations gain depths in the upper water column $<500 \mathrm{~m} .{ }^{234} \mathrm{Th}$ data contribute $32 \%$ of all POC flux estimates resolved at depths between 100 and $200 \mathrm{~m}$ (Fig. 5a). Overall, the most common deployment depths are between 1000 and $1500 \mathrm{~m}$ (14\%) followed by 200 to $300 \mathrm{~m}(11 \%)$ and then 3000 to $3500 \mathrm{~m}$ (9\%) (Fig. 5b). The dominance of the 1000 to $1500 \mathrm{~m}$ observation depth is weighted to the presatellite era (Fig. 5c). During the satellite era, 200 to $300 \mathrm{~m}$ $(6 \%)$ became the most sampled depth, largely due to persistent time series observations at BATS and OSP, followed closely by the 1000 to 1500 and 3000 to $3500 \mathrm{~m}$ bins $(5 \%$ each) again the result of time series observations at CARIACO and OFP (Fig. 5d). Reasonable depth resolution is found in the observations coincident with satellite matchups (Fig. 5d).

\section{Conclusions}

This data set is the most comprehensive compilation of POC flux across the globe that we are aware of. By providing merged coincident satellite imagery products, the data set can immediately be used to link phytoplankton surface process with POC flux. Due to rapid remineralization within the first $500 \mathrm{~m}$ of the water column, shallow observations from ${ }^{234} \mathrm{Th}$ are helpful to supplement the more extensive sediment trap record. The data compilation is also insightful in terms of spatial and depth resolution to aid in decision making for future POC flux observing investments.

\section{Data availability}

The data set contains 15792 individual POC flux estimates at 674 unique locations collected between 1976 and 2012. Where available, the flux of other minerals is also reported. $43 \%$ (6842) of POC flux measurements overlap with the SeaWiFS satellite record (September 1997 to December 2010). Satellite parameters in this compilation include: chlorophyll concentration, net primary production, sea surface temperature, diffuse attenuation coefficient, euphotic depth, photosynthetically active radiation, and microplankton fraction. Estimated mixed layer depths and bathymetry are also provided. Parameters associated with observation sites are extracted as the median of a $5 \times 5$ (chlorophyll concentration, NPP, $K_{\mathrm{d}}(490)$, PAR and $\left.S_{\mathrm{fm}}\right), 11 \times 11$ (SST), or $1 \times 1$ (MLD, bathymetry) pixel box. The compiled data are available on PANGAEA (https://www.pangaea.de/): doi:10.1594/PANGAEA.855600 (Mouw et al., 2016).

Author contributions. C. B. Mouw and G. A. McKinley conceived the project and acquired funding for the effort. C. B. Mouw and A. Barnett designed the data compilation. A. Barnett retrieved and processed all data and prepared figures. C. B. Mouw and A. Barnett prepared the manuscript with contributions from all co-authors.

Acknowledgements. We would like to thank the Ocean Color Processing Group at NASA GSFC for the processing and distribution of the SeaWiFS imagery and the IFREMER/LOS Mixed Layer Depth Climatology group for retrieval and distribution of MLD estimates. We would also like to thank BCO-DMO, NOAA National Centers for Environmental Information, the US JGOFS Data System at WHOI, JAMSTEC, Fisheries and Oceans Canada, and the time series efforts at BATS, OFP, OSP, CARIACO and HOT for continued collection and hosting of publicly available data sets. We would like to thank Makio C. Honda for sending data from locations in the northwest Pacific, Walker O. Smith Jr. for sharing data from the Ross Sea, Maureen Conte for sharing the OFP archive, David Timothy and Roy Hourston for providing the OSP data set, Bradley Moran for providing the arctic data set, and John Dunne for sharing the Dunne et al. (2005) data compilation. The National Aeronautics and Space Administration (NNX11AD59G and NNX13AC34G) provided financial support for this data compilation effort. This is contribution number 38 of the Great Lakes Research Center at Michigan Technological University.

Edited by: R. Key

Reviewed by: J. Dunne and one anonymous referee 


\section{References}

Amante, C. and Eakins, B. W.: ETOPO1 1 Arc-Minute Global Relief Model: Procedures, Data Sources and Analysis, NOAA Technical Memorandum NESDIS NGDC-24, National Geophysical Data Center, NOAA, doi:10.7289/V5C8276M, 2009.

Bailey, S. and Werdell, P.: A multi-sensor approach for the on-orbit validation of ocean color satellite data products, Remote Sens. Environ., 102, 12-23, doi:10.1016/j.rse.2006.01.015, 2006.

Behrenfeld, M. and Falkowski, P.: Photosynthetic rates derived from satellite-based chlorophyll concentration, Limnol. Oceanogr., 42, 1-20, 1997.

Buesseler, K. O.: Do upper-ocean sediment traps provide an accurate record of particle flux?, Nature, 353, 420-423, 1991.

Buesseler, K. O. and Boyd, P. W.: Shedding light on processes that control particle export and flux attenuation in the twilight zone of the open ocean, Limnol. Oceanogr., 54, 1210-1232, 2009.

Buesseler, K. O., Steinberg, D. K., Michaels, A. G., Johnson, R. J., Andrews, J. E., Valdes, J. R., and Price, J. F.: A comparison of the quality and composition of material caught in a neutrally buoyant versus surface-tethered sediment trap, Deep-Sea Res. Pt. I, 47, 227-294, doi:10.1016/S0967-0637(99)00056-4, 2000.

Buesseler, K. O., Barber, R. T., Dickson, M.-L., Hiscock, M. R., Moore, J. K., and Sambrotto, R.: The effect of marginal ice-edge dynamics on production and export in the Southern Ocean along $170^{\circ}$ W, Deep-Sea Res. Pt. II, 50, 579-603, doi:10.1016/S09670645(02)00585-4, 2003.

Casey, K. S., Brandon, T. B., Cornillon, P., and Evans, R.: The Past, Present, and Future of the AVHRR Pathfinder SST Program, in: Oceanography from Space, 273-287, Dordrecht: Springer, the Netherlands, doi:10.1007/978-90-481-8681-5_16, 2010.

Church, M. J. and Karl, D. M.: Primary production and sediment trap flux measurements and calculations by the Hawaii Ocean Time-series (HOT) program at Station ALOHA in the North Pacific 100 miles north of Oahu, Hawaii for Cruises HOT1-227 during 1988-2010, NOAA National Centers for Environmental Information, Accession: 0089168, available at: http://data.nodc. noaa.gov/accession/0089168 (last access: 14 May 2012), 2013.

Ciotti, A. and Bricaud, A.: Retrievals of a size parameter for phytoplankton and spectral light absorption by colored detrital matter from water-leaving radiances at SeaWiFS channels in a continental shelf region off Brazil, Limnol. Oceanogr.-Meth., 4, 237-253, 2006.

Ciotti, A., Lewis, M., and Cullen, J.: Assessment of the relationship between dominant cell size in natural phytoplankton communities and the spectral shape of the absorption coefficient, Limnol. Oceanogr., 47, 404-417, 2002.

Cochran, J. K., Barnes, C., Achman, D., and Hirshberg, D. J.: Thorium-234/Uranium-238 disequilibrium as an indicator of scavenging rates and particulate organic carbon fluxes in the Northeast Water Polyna, Greenland, J. Geophys. Res., 100, 4399-4410, doi:10.1029/94JC01954, 1995.

Cochran, J. K., Buesseler, K. O., Bacon, M. P., Wang, H. W., Hirschberg, D. J., Ball, L., Andrews, J., Crossin, G., and Fleer, A.: Short-lived isotopes $\left({ }^{234} \mathrm{Th},{ }^{228} \mathrm{Th}\right)$ as indicators of POC export and particle cycling in the Ross Sea, Southern Ocean, Deep-Sea Res. Pt. II, 47, 3451-3490, doi:10.1016/S09670645(00)00075-8, 2000.
Collier, R. and Dymond, J.: Sed_trap_annual, Biological and Chemical Oceanography Data System, BCO DMO, WHOI, available at: http://www.bco-dmo.org/dataset/2608 (last access: 17 September 2013), 1994a.

Collier, R. and Dymond, J.: Sed_trap_Eq_North, Biological and Chemical Oceanography Data System, BCO DMO, WHOI, available at: http://www.bco-dmo.org/dataset/2609 (last access: 17 September 2013), 1994b.

Collier, R., Dymond, J., Honjo, S., Manganini, S., Francois, R., and Dunbar, R.: The vertical flux of biogenic and lithogenic material in the Ross Sea: moored sediment trap observations 19961998, Deep-Sea Res. Pt. II, 47, 3491-3520, doi:10.1016/S09670645(00)00076-X, 2000.

Collins, L. E., Berelson, W., Hammond, D. E., Knapp, A., Schwartz, R., and Capone, D.: Particle fluxes in San Pedro Basin, California: A four-year record of sedimentation and physical forcing, Deep-Sea Res. Pt. I, 58, 898-914, doi:10.1016/j.dsr.2011.06.008, 2011.

de Boyer Montégut, C., Madec, G., Fischer, A. S., Lazar, A., and Iudicone, D.: Mixed layer depth over the global ocean: an examination of profile data and a profile-based climatology, J. Geophys. Res., 109, C12003, doi:10.1029/2004JC002378, 2004.

de Boyer Montégut, C., Mignot, J., Lazar, A., and Cravatte, S.: Control of salinity on the mixed layer depth in the world ocean: 1. General description, J. Geophys. Res., 112, C06011, doi:10.1029/2006JC003953, 2007.

Dunne, J., Armstrong, R., Gnanadesikan, A., and Sarmiento, J.: Empirical and mechanistic models for the particle export ratio, Global Biogeochem. Cy., 19, GB4026, doi:10.1029/2004GB002390, 2005.

Dunne, J. P., Murray, J. W., Rodier, M., and Hansell, D. A.: Export flux in the western and central equatorial Pacific: Zonal and temporal variability, Deep-Sea Res. Pt. I, 47, 901-936, doi:10.1016/S0967-0637(99)00089-8, 2000.

Frouin, R., Franz, B. A., and Werdell, P. J.: The SeaWiFS PAR product, in: Algorithm Updates for the Fourth SeaWiFS Data Reprocessing, edited by: Hooker, S. B. and Firestone, E. R., NASA Tech. Memo. 2003-206892, Vol. 22, NASA Goddard Space Flight Center, Greenbelt, Maryland, 46-50, 2002.

Guidi, L., Legendre, L., Reygondeau, G., Uitz, J., Stemmann, L., and Henson, S. A.: A new look at ocean carbon remineralization for estimating deepwater sequestration, Global Biogeochem. Cy., 29, 1044-1059, doi:10.1002/2014GB005063, 2015.

Henson, S. A., Sanders, R., Madsen, E., Morris, P. J., Le Moigne, F., and Quartly, G. D.: A reduced estimate of the strength of the ocean's biological carbon pump, Geophys. Res. Lett., 38, L04606, doi:10.1029/2011GL046735, 2011.

Henson, S. A., Sanders, R., and Madsen, E.: Global patterns in efficiency of particulate organic carbon export and transfer to the deep ocean, Global Biogeochem. Cy., 26, GB1028, doi:10.1029/2011GB004099, 2012.

Honda, M. C.: JAMSTEC Sediment trap data at time-series stations: K2 and S1 for Ocean SITES, JAMSTEC Environmental Biogeochemical Cycle Research Program, available at: http://ebcrpa.jamstec.go.jp/rigc/e/ebcrp/mbcrt/st_k2s1_ oceansites/ (last access: 10 April 2014), 2012.

Honda, M. C., Imai, K., Norjiri, Y., Hoshi, F., Sugawara, T., and Kusakabe, M.: The biological pump in the northwestern North Pacific based on fluxes and major components of par- 
ticulate matter obtained by sediment-trap experiments (19972000), Deep-Sea Res. Pt. II, 49, 5595-5625, doi:10.1016/S09670645(02)00201-1, 2002.

Honjo, S.: Sediment Properties and other data from a fixed platform from 19941102 to 19951205 , NOAA National Centers for Environmental Information, Accession: 9800155, available at: http: //www.nodc.noaa.gov/cgi-bin/OAS/prd/accession/9800155 (last access: 3 October 2013), 1999.

Honjo, S. and Dymond, J.: Sed_trap_Eq_South, Biological and Chemical Oceanography Data System, BCO DMO, WHOI, available at: http://www.bco-dmo.org/dataset/2618 (last access: 17 September 2013), 1994.

Honjo, S. and Dymond, J.: Deep sea sediment trap particle flux, AESOPS/Southern Ocean 1996-1997 Mooring Deployment, US JGOFS Data System, available at: http://usjgofs.whoi.edu/jg/dir/ jgofs/southern/ (last access: 9 April 2014), 2002.

Honjo, S. and Maganini, S.: Sediment trap data, biogenic particle fluxes North Atlantic Bloom Experiment, US JGOFS Data System, available at: http://usjgofs.whoi.edu/jg/dir/jgofs/nabe/ (last access: 9 April 2014), 1995.

Honjo, S., Manganini, S. J., Krishfield, R. A., and Francois, R.: Particulate organic carbon fluxes to the ocean interior and factors controlling the biological pump: A synthesis of global sediment trap programs since 1983. Prog. Oceanogr., 76, 217-285, doi:10.1016/j.pocean.2007.11.003, 2008.

Kawakami, H., and Honda, M. C.: Time-series observation of POC fluxes estimated from ${ }^{234} \mathrm{Th}$ in the northwestern North Pacific, Deep-Sea Res. Pt. I, 54, 1070-1090, doi:10.1016/j.dsr.2007.04.005, 2007.

Kuhnt, T., Howa, H., Schmidt, S., Marié, L., and Scheibel, R.: Flux dynamics of planktonic foraminiferal test in the south-eastern Bay of Biscay (northeast Atlantic margin), J. Marine Syst., 109110, S169-S181, doi:10.1016/j.jmarsys.2011.11.026, 2013.

Lam, P. J., Doney, S. C., and Bishop, J. K. B.: The dynamic ocean biological pump: Insights from a global compilation of particulate organic carbon, $\mathrm{CaCO}_{3}$, and opal concentration profiles from the mesopelagic, Global Biogeochem. Cy., 25, GB3009, doi:10.1029/2010GB003868, 2011.

Lamborg, C. H., Buesseler, K. O., Valdes, J., Bertrand, C. H., Bidigare, R., Manganini, S., Pike, S., Steinberg, D., Trull, T., and Wilson, S.: The flux of bio- and lithogenic material associated with sinking particles in the mesopelagic "twilight zone" of the northwest and North Central Pacific Ocean, Deep-Sea Res. Pt. II, 55, 1540-1563, doi:10.1016/j.dsr2.2008.04.011, 2008.

Lee, C.: Sediment Trap Mass Flux, MedFlux, Biological and Chemical Oceanography Data System, BCO DMO, WHOI, available at: http://www.bco-dmo.org/dataset/3561 (last access: 22 May 2013), 2011.

Lee, C., Hedges, J. I., Wakeham, S. G., and Zhu, N.: Effectiveness of various treatments in retarding microbial activity in sediment trap material and their effects on the collection of swimmers, Limnol. Oceanogr., 37, 117-130, doi:10.4319/lo.1992.37.1.0117, 1992.

Lima, I. D., Lam, P. J., and Doney, S. C.: Dynamics of particulate organic carbon flux in a global ocean model, Biogeosciences, 11, 1177-1198, doi:10.5194/bg-11-1177-2014, 2014.

Lomas, M. W., Nelson, D. M., Lipschultz, F., Knap, A., and Bates, N.: Trap Flux, Biological and Chemical Oceanography Data System, BCO DMO, WHOI, available at: http://www.bco-dmo.org/ dataset/3215 (last access: 22 May 2013), 2009.
Lomas, M. W., Roberts, N., Lipschultz, F., Krause, J. W., Nelson, D. M., and Bates, N. R.: Biogeochemical responses to latewinter storms in the Sargasso Sea. IV. Rapid succession of major phytoplankton groups, Deep-Sea Res. Pt. I, 56, 892-908, doi:10.1016/j.dsr.2009.03.004, 2009.

Lutz, M. J., Calderia, K., Dunbar, R. B., and Behrenfeld, M. J.: Seasonal rhythms of net primary production and particulate organic carbon flux to depth describe the efficiency of biological pump in the global ocean. J. Geophys. Res., 112, C100110, doi:10.1029/2006JC003706, 2007.

Maritorena, S., Siegel, D., and Peterson, A.: Optimization of a semianalytical ocean color model for global-scale applications, Appl. Optics, 41, 2705-2714, 2002.

Martin, J. H., Knauer, G., Karl, D., and Broenkow, W.: VERTEX: Carbon cycling in the northeast Pacific, Deep-Sea Res. Pt. I, 34 267-285, 1987.

Martin, P., Lampitt, R. S., Perry, M. J., Sanders, R., Lee, C., and D'Asaro, E.: Export and mesopelagic particle flux during a North Atlantic spring diatom bloom, Deep-Sea Res. Pt. I, 58, 338-349, doi:10.1016/j.dsr.2011.01.006, 2011.

Mignot, J., de Boyer Montégut, C., Lazar, A., and Cravatte, S.: Control of salinity on the mixed layer depth in the world ocean: 2. Tropical areas, J. Geophys. Res., 112, C10010, doi:10.1029/2006JC003954, 2007.

Mohiuddin, M. M., Nishimura, A., Tanaka, Y., and Shimamoto, A.: Regional and interannual productivity of biogenic components and planktonic foraminiferal fluxes in the northwestern Pacific Basin, Mar. Micropaleontol., 45, 57-82, doi:10.1016/S03778398(01)00045-7, 2002.

Mohiuddin, M. M., Nishimura, A., Tanaka, Y., and Shimamoto, A.: Seasonality of biogenic particle and planktonic foraminifera fluxes: response to hydrographic variability in the Kuroshio Extension, northwestern Pacific Ocean, Deep-Sea Res. Pt. I, 51, 1659-1683, doi:10.1016/j.dsr.2004.06.002, 2004.

Montes, E., Muller-Karger, F., Thunell, R., Hollander, D., Astor, Y., Varela, R., Soto, I., and Lorenzoni, L.: Vertical fluxes of particulate biogenic material through the euphotic and twilight zones in the Cariaco Basin, Venezuela, Deep-Sea Res. Pt. I, 67, 73-84, doi:10.1016/j.dsr.2012.05.005, 2012.

Moran, S. B., Lomas, M. W., Kelly, R. P., Gradinger, R., Iken, K., and Mathis, J. T.: Seasonal succession of net primary productivity, particulate organic carbon export, and autrophic community composition in the eastern Bering Sea, Deep-Sea Res. Pt. II, 6570, 84-97, doi:10.1016/j.dsr2.2012.02.011, 2012.

Morel, A. and Berthon, J.-F.: Surface pigments, algal biomass, and potential production of the euphotic layer: relationships reinvestigation in view of remote-sensing applications, Limnol. Oceanogr., 8, 1545-1562, 1989.

Mouw, C. and Yoder, J.: Optical determination of phytoplankton size composition from global SeaWiFS imagery, J. Geophys. Res., 115, C12018, doi:10.1029/2010JC006337, 2010.

Mouw, C. B., Barnett, A., McKinley, G., Gloege, L., and Pilcher, D.: Global Ocean Particulate Organic Carbon flux merged with satellite parameters, PANGAEA, doi:10.1594/PANGAEA.855600, 2016.

Murray, J. W., Young, J., Newton, J., Dunne, J., Chapin, T., Paul, B., and McCarthy, J. J.: Export flux of particulate organic carbon from the central equatorial Pacific determined using a combined 
drifting trap-234Th approach, Deep-Sea Res. Pt. II, 43, 10951132, doi:10.1016/0967-0645(96)00036-7, 1996.

Newton, J. and Murray, J. W.: Poc_pn_trap, Biological and Chemical Oceanography Data System, BCO DMO, WHOI, available at: http://www.bco-dmo.org/dataset-deployment/450839 (last access: 18 September 2013), 1995a.

Newton, J. and Murray, J. W.: Poc_pn_trap, Biological and Chemical Oceanography Data System, BCO DMO, WHOI, available at: http://www.bco-dmo.org/dataset-deployment/450925 (last access: 18 September 2013), 1995b.

O’Reilly, J. E., Maritorena, S., O’Brien, M. C., Siegel, D. A., Toole, D., Menzies, D., Smith, R. C., Muller, J. L., Mitchell, B. G., Kahru, M., Chavez, F. P., Strutton, P., Cota, G. F., Hooker, S. B., McClain, C. R., Carder, K. L., Muller-Karger, F., Harding, L., Magnuson, A., Phinny, D., Moore, G. F., Aiken, J., Arrigo, K. R., Letelier, R., and Culver, M.: SeaWiFS Postlaunch Calibration and Validation Analyses, Part 3, NASA Tech. Memo. 2000-206892, Vol. 11, edited by: Hooker, S. B. and Firestone, E. R., NASA Goddard Space Flight Center, 49 pp., 2000.

Quay, P.: Was a carbon balance measured in the equatorial $\mathrm{Pa}$ cific during JGOFS?, Deep-Sea Res. Pt. II, 44, 1765-1781, doi:10.1016/S0967-0645(97)00093-3, 1997.

Rigual-Hernández, A., Bárcena, M. A., Jordan, R. W., Sierro, R. J., Flores, J. A., Meier, K. J. S., Beaufort, L., and Heussner, S.: Diatom fluxes in the NW Mediterranean: evidence from a 12-year sediment trap record and surficial sediments, J. Plankton Res., 35, 1109-1225, doi:10.1093/plankt/fbt055, 2013.

Smith Jr., W. O., Shields, A. R., Dreyer, J. C., Peloquin, J. A., and Asper, V.: Interannual variability in vertical export in the Ross Sea: Magnitude, composition and environmental correlates, Deep-Sea Res. Pt. I, 58, 147-159, doi:10.1016/j.dsr.2010.11.007, 2011.
Tesi, T., Ravaioli, L. M., Giglio, F., and Capotondi, L.: Particulate export and lateral advection in the Antarctic Polar Front (Southern Pacific Ocean): One-year mooring deployment, J. Marine Syst., 105-108, 70-81, doi:10.1016/j.jmarsys.2012.06.002, 2012.

Thurnell, R. C.: Sediment Trap Data, CARIACO Ocean Time Series Data, available at: http://imars.marine.usf.edu/CAR/index.html (last access: 13 September 2013), 2013.

Timothy, D. A., Wong, C. S., Barwell-Clarke, J. E., Page, J. S., White, L. A., and Macdonald, R. W.: Climatology of sediment flux and composition in the subarctic Northeast Pacific Ocean with biogeochemical implications. Prog. Oceanogr., 116, 95129, doi:10.1016/j.pocean.2013.06.017, 2013.

Torres Valdés, S., Painter, S. C., Martin, A. P., Sanders, R., and Felden, J.: Data compilation of fluxes of sedimenting material from sediment traps in the Atlantic Ocean, Earth Syst. Sci. Data, 6, 123-145, doi:10.5194/essd-6-123-2014, 2014.

van der Loeff, M. R., Sarin, M. M., Baskaran, M., Benitez-Nelson, C., Buesseler, K. O., Charette, M., Dai, M., Gustafsson, O., Masque, P., Morris, P. J., Orlandini, K., y Baena, A. R., Savoye, N., Schmidt, S., Turnewitsch, R., Vöge, I., and Waples, J. T.: A review of present techniques and methodological advances in analyzing ${ }^{234} \mathrm{Th}$ in aquatic systems, Mar. Chem., 100, 190-212, doi:10.1016/j.marchem.2005.10.012, 2006.

Wassmann, P., Bauerfind, E., Fortier, M., Fukuchi, M., Hargrave, B., Moran, S. B., Noji, T., Nöthig, E.-M., Olli, K., Peinert, R., Sasaki, H., and Shevchenko, V. P.: Particulate organic carbon flux to the Arctic Ocean sea floor, in: The Organic Carbon Cycle in the Arctic Ocean, edited by: Stein, R. and Macdonald, R. W., Springer-Verlag, Heidelberg-Berlin-NewYork, 102-138, 2003. 